\title{
Genetic variation and response to selection for storage root dry matter and associated traits in a population of yam bean (Pachyrhizus spp.) interspecies crosses
}

\author{
Rolland Agaba $(\mathbb{D} \cdot$ Patrick Rubaihayo $\cdot$ Phinehas Tukamuhabwa $(\mathbb{D} \cdot$ \\ Robert O. M. Mwanga (i) - Silver Tumwegamire (i) - Jean Ndirigwe (i) \\ Bettina Heider $(\mathbb{D} \cdot$ - Wolfgang Grüneberg $(\mathbb{D})$
}

Received: 3 February 2020/ Accepted: 24 January 2021 / Published online: 22 March 2021

(C) The Author(s) 2021

\begin{abstract}
The goal of yam bean improvement in Africa is to develop superior high yielding and high dry matter cultivars that are preferred for adoption. In this study, the estimates of variance components, heritability and response to selection were studied in $\mathrm{F}_{3}$ yam bean families selected from interspecies crosses targeting improvement of storage root dry matter and associated traits. Breeding populations were generated using North Carolina II (NC II) mating design involving high dry matter $P$. tuberosus chuin cultivar, low dry matter $P$. ahipa and the high yielding $P$. erosus yam beans. The progenies were advanced through selfing from $F_{1}$ to $F_{2}$ population and then exposed to selection at $10 \%$ selection intensity to obtain 83 high dry matter lines. The selected lines were evaluated in an $F_{3}$ trial using a randomized complete block design (RCBD) with three replications at the National Crops Resources Research Institute
\end{abstract}

R. Agaba $(\bowtie) \cdot$ P. Rubaihayo · P. Tukamuhabwa Department of Agricultural Production, Makerere University, P.O Box 7062, Kampala, Uganda

e-mail: rondessblessed@gmail.com

\section{R. Agaba}

Kachwekano Zonal Agricultural Research and

Development Institute, National Agricultural Research

Organisation (NARO), P.O Box 421, Kabale, Uganda

R. O. M. Mwanga - S. Tumwegamire International Potato Center (CIP),

P.O Box 22274, Kampala, Uganda
(NaCRRI) Namulonge, in Central Uganda. The results revealed significant $(P<0.001)$ genetic variation for storage root dry matter (RDM), storage root fresh yield (RFY), storage root dry yield (RDY), vine yield (VNY), fresh biomass yield (FBY), harvest index (HI), starch (STA) and protein (PRO) content. High genotypic coefficient of variation (GCV) and phenotypic coefficient of variation (PCV) were obtained for VNY, RDY, FBY, RFY, RDM and STA. Narrow sense heritability was higher than 0.5 and response to selection was 15.5 to 33.1 for RDM, RFY, RDY, VNY, FBY and STA, indicating rapid genetic progress is achievable and early generation selection would be effective to improve these traits. Significant $(P<0.01)$ positive genetic correlations were observed between RDM, RDY, RFY, VNY, FBY and STA ranging from 0.422 to 0.963 implying that

\author{
S. Tumwegamire \\ Central Africa Hub, IITA Kigali, P.O Box 1269, Kigali, \\ Rwanda \\ J. Ndirigwe \\ Rwanda Agriculture Board, Roots and Tubers \\ Programme, P.O Box 7231, Kigali, Rwanda \\ B. Heider · W. Grüneberg \\ International Potato Center (CIP), La Molina 1895, Lima \\ 12, 1558, Apartado, Peru
}


simultaneous improvement of these traits is possible in the current yam bean populations.

Keywords Genetic parameters - Dry matter content Storage root yield $\cdot$ Interspecific crosses $\cdot$ Selection response Y Yam beans

\section{Introduction}

There is a growing interest in research and development of neglected legume root crops, as potential sources of food rich in protein and micronutrients to alleviate nutritional deficiencies especially in the developing world (Popoola et al. 2019). Yam bean is one among many underutilised storage root forming legumes that attracts researchers in Africa (Zanklan et al. 2018), where the crop was introduced to augment food and nutritional security, enhance sustainability of farming systems through biological nitrogen fixation (Grüneberg 2016; Heider et al. 2011), and diversify diets of root crop dependent communities (Agaba et al. 2016). The yam bean is a legume root crop belonging to the genus Pachyrhizus (Grum 1994; Sørensen 1996). There are three cultivated yam bean species that are traditionally grown in the Americas and Asia as a vegetable root crop (Sørensen 1990). The cultivated yam beans are: the Amazonian yam bean (P. tuberosus) from South America, the Mexican yam bean ( $P$. erosus) from Central America, and the Andean yam bean ( $P$. ahipa) from subtropical Andean valleys of South America (Sørensen 1996). Among the three cultivated yam bean species, only $P$. tuberosus is divided into four cultivar groups: 'Chuin', 'Ashipa', 'Yushpe' and 'Jiquima' landraces found in the Amazonian river basin (Tapia and Sørensen 2003).

Yam bean storage roots are usually consumed raw as a root vegetable or salad in native America (Gupta et al. 2003; Ramos-de-la-Peña et al. 2012) and Asia (Primiani 2005) because the roots have high moisture content of more than $80 \%$ of fresh weight (Grüneberg et al. 1999; Santayana et al. 2014). In Africa, the yam bean storage roots have been used to make a varied range of processed products such as flour used in bakery, food stuffs, liquor and snacks (Adegbola et al. 2015). The low storage root dry matter content of yam beans at an average of $20 \%$ plus a refreshing taste could explain the usage in salads (Agaba et al. 2016) but this trait limits its potential in Africa where high dry matter is a preferred trait for processing root crops into local food products such as gari, atapa, ugali, porridge, and pancakes (Grüneberg 2016). However, a recently discovered chuin cultivar of $P$. tuberosus around the Rio Ucayali River in Peru has low moisture content (about 70\%) and dry matter content of 26-36\% which is considered high in the yam bean gene pool (Grüneberg et al. 2003; Zanklan et al. 2007). The chuin and Yushpe cultivars of P.tuberosus have elevated dry matter among the cultivated yam bean species (Delêtre et al. 2017). In fact, the chuin cultivar is cooked and consumed like cassava from the root of the manioc plant by farming communities in Peru (Grüneberg et al. 2003; Zanklan et al. 2018).

The availability of the chuin cultivar offers opportunities to improve storage root dry matter content in yam beans through intraspecific and interspecific hybridisation (Grüneberg 2016; Grüneberg et al. 2003). The chuin could be utilized in breeding programs as a source of genes to develop high dry matter cultivars that combine the high yields of $P$. erosus and early maturity of $P$. ahipa. Fortunately, interspecific compatibility of the three cultivated yam bean species; $P$. erosus, $P$. ahipa and $P$. tuberosus results in fertile and vigorous hybrids (Grüneberg et al. 2003). There are no crossing barriers and frequencies of successful interspecific recombination is high among the three yam beans species (Grüneberg 2016), implying a high dry matter breeding population can be easily developed to improve dry matter content in the entire yam bean gene pool (Agaba et al. 2016). This interspecies compatibility is the reason recent research by Agaba et al. (2016) and (Zanklan et al. 2018) hypothesised that the three yam bean species belong to one primary gene pool. Delêtre et al. (2017) reported that $P$. ahipa and $P$. tuberosus could be sharing progenitor derivative relationships in their evolution and domestication history in the Andes but environmental factors could have influenced selection for divergent ecotypes.

High dry matter yam bean cultivars have been proposed as the most important goal for future improvement programs in Africa (Agaba et al. 2017). Recent research by Zanklan et al. 2018 stated that breeding is aiming to combine the wide adaptation of $P$. erosus, the storage root quality of the chuin cultivar of $P$. tuberosus and the bushy-erect growth type, early maturity and day length insensitivity of $P$. 
ahipa so as to improve the agronomy, yields and quality traits of the yam beans. However, the success of breeding programs depends largely on the magnitude of genetic variability present in the base population and selection of parents with good combining ability for the trait of interest.

Fortunately, several studies have reported high genetic variation for agronomic and morphological traits throughout the yam bean species (Agaba et al. 2016; da Silva et al. 2016; Santayana et al. 2014; Zanklan et al. 2018) which presents opportunities for genetic improvement through hybridisation and selection. The above studies followed ealier research by Tapia and Sørensen (2003), which observed high genetic variation in $P$. tuberosus species and recommended studies to determine response to selection for morphological traits in yam beans. Also, combining ability analysis for quantitative traits, by Jha and Singh (2014) reported positive and significant GCA and SCA effects and predominance of additive gene effects for quantitative traits such as root yield, earliness, root length and storage root girth and volume in the Mexican yam bean ( $P$. erosus species). The gap is that these studies did not investigate inheritance of agronomic traits and response to selection for storage root dry matter, a trait most valued by famers for adoption and sustainable cultivation of yam beans in Africa.

Against this background, Agaba et al. (2017), investigated inheritance of storage root dry matter and revealed significant GCA and SCA effects and high heritability for dry matter content and associated traits in interspecies yam bean breeding populations. The findings suggested that expression of root dry matter is controlled by additive gene effects with potential for quick responses to early generation selection. Early generation selection has been previously reported to be effective in identifying superior breeding lines and selection response which increases with additive effects and high heritability (Yang 2009). Selection based on storage root shape and size, growth habit, pest resistance, and seed yield in $P$. erosus resulted in the development of high yielding cultivars in Mexico (Sørensen, 1996). However, these selection experiments did not estimate the response to selection and never used the high dry matter chuin cultivar of $P$. tuberosus as parent for interspecies hybridisation to assess improvement potential for storage root yields and dry matter in the yam beans.
Even with research for nearly two decades in Africa, the yam bean is yet to be widely adopted or prioritized by research institutions, farmers and agroindustries mainly because the storage roots are low in dry matter content $(<25 \%)$ (Agaba et al. 2017). The popular root crops such as cassava, sweetpotato, and yams are preferred given they have high dry matter content for consumption and industrial applications (Tumwegamire et al. 2011). This makes the yam beans less competitive for instance in making a popular root crop food, "gari" often made from cassava (Padonou et al. 2013). However, yam beans are rich in protein, zinc and iron which accounts for enormous food nutrient deficiencies in Sub Saharan Africa (Gegios et al. 2010). Yam beans should be popularised not as a competition to existing root crops but as a source of protein and micronutrients to root crop dependent communities. Nevertheless, a high dry matter yam bean would be easy to promote for adoption among small holder farmers (Agaba et al. 2017).

The knowledge of genetic parameters for desirable traits is a prerequisite for success of crop improvement programs (Roychowdhury et al. 2012), more so in yam beans where genetic studies are limited. To date, there are no studies reporting the response to selection for dry matter and related traits in yam beans despite the hypothesised importance of this trait to make the crop more attractive for adoption, utilisation, and processing. This study estimated variance components, heritability, and response to selection for storage root dry matter content (RDM) and associated traits [(i.e. root fresh yield (RFY), root dry yield (RDY), harvest index (HI), fresh biomass yield (FBY), vine yield (VNY), protein (PRO), and starch (STA)] in selected families of $\mathrm{F}_{3}$ yam bean populations. According to OloyedeKamiyo et al. (2014), the estimation of genetic variances helps plant breeders to choose the most efficient breeding design for improving crops within the available resources. The information from the current study will inform breeders to select appropriate breeding procedures and design effective yam bean improvement programs targeting high yielding and high dry matter yam bean cultivars for adoption in Africa. 


\section{Material and methods}

\section{Experimental sites}

The experiments were carried out under field conditions at the National Crops Resources Research Institute (NaCRRI), Namulonge, Wakiso District, Central Uganda starting in April 2015. Namulonge is located at $32^{\circ} 36^{\prime \prime} \mathrm{E}$ and $0^{\circ} 31^{\prime \prime} \mathrm{N}$, at $1150 \mathrm{~m}$ above sea level, and has a bimodal rainfall pattern with a mean of $1,270 \mathrm{~mm}$ and two distinct rainy and dry seasons of nearly equal length. The site has a mean annual temperature of $22.2{ }^{\circ} \mathrm{C}$ ranging from 15.9 to $28.9^{\circ} \mathrm{C}$ (Tumuhimbise et al. 2014) with reddish brown clay loam soils of $\mathrm{pH}$ 5.4-5.9 and is covered with savanna vegetation type (Ddamulira et al. 2015).

\section{Germplasm and Hybridisation}

Three yam bean species namely; $P$. tuberosus, $P$. erosus, and $P$. ahipa constituted the parental material which was selected from yam bean accessions obtained from the International Potato Center (CIP) plant gene bank in Lima, Peru (Agaba et al. 2016; Grüneberg 2016). The chuin cultivar with high storage root dry matter (RDM > 30\%) (Tapia and Sørensen 2003) was chosen as a potential good source of high dry matter trait for yam bean improvement (Grüneberg et al. 2003; Zanklan et al. 2007). The $P$. erosus species were chosen for high yields (Sørensen 1996) and $P$. ahipa for early maturity with a semi erect growth habit (Grüneberg 2016). The parental genotypes including P. tuberosus chuin accessions (209013, 209014 and 209015), P. ahipa accessions (209004, 209016, and 209022) and P. erosus accessions (209018, 209019, and 209031) were selected for hybridisation. The characteristics of the parents are listed in Table 1.

During hybridisation, the three high dry matter $P$. tuberosus chuin cultivars were crossed with six low dry matter parents consisting of three $P$. ahipa and three $P$. erosus accessions following North Carolina Design II (NCD II) mating design to generate $F_{1}$ population of sixteen crosses (Table 2). Eighteen $F_{1}$ crosses were expected but two cross combinations namely, $201915 \times 209022$ and $209015 \times 209031$ were not realised due to persistent flower abortions.
Selection and progeny evaluation

The crosses were advanced to $F_{2}$ population in a progeny trial grown under field conditions at NaCRRI Namulonge, using randomised complete block design (RCBD) with three replications. Then, from the 830 lines in the $\mathrm{F}_{2}$ population, 83 lines (10\%) were selected using highest dry matter yield as the selection criteria. Selection at $10 \%$ is moderate and suitable for early generation selections such as in $\mathrm{F}_{2}$ when segregation is highest. A moderated selection allows that populations selected contain genotypes with the desired traits and gene combinations.

The 83 lines were grouped according to the 16 crosses to which they belonged and evaluated in an $\mathrm{F}_{3}$ trial in the field at NaCRRI, during the first rainy season in April 2015 for estimation of variance components, heritability and response to selection for RDM and associated traits. The 83 lines were sown using five seeds per plot at a spacing of $0.3 \mathrm{~m}$ between plants. Plots consisted of ridges measuring $1.5 \mathrm{~m}$ long and $1 \mathrm{~m}$ apart. The plots were arranged in a RCBD with three replications. The experimental field was kept weed free and no reproductive pruning of flowers or fertilizers or agrochemicals were applied during the crop growth cycle.

Data collection

The trial was harvested at maturity, 6 months after planting and data recorded on weight of fresh storage roots (WFR) and above ground foliage (vine weight, WVN). These traits were used to estimate storage root fresh yield (RFY t ha ${ }^{-1}$ ), vine yield (VNY $\mathrm{t} \mathrm{ha}^{-1}$ ), fresh biomass yield $(\mathrm{FBY}=\mathrm{RFY}+\mathrm{VNY}) \mathrm{t} \mathrm{ha}^{-1}$, and harvest index $(\mathrm{HI}=\mathrm{RFY} / \mathrm{FBY})$ as percentage.

From each plant, two storage roots were selected to constitute a sample for determination of storage root dry matter (RDM), starch and protein content at the Nutritional Quality Laboratory (NQL) at NaCRRI. At the laboratory, the samples were washed, peeled and sliced to prepare compound samples of $100 \mathrm{~g}$ fresh weight. Then, each sample was packaged in a transparent polythene bag and freeze dried at $-31{ }^{\circ} \mathrm{C}$ for $72 \mathrm{~h}$ (using a vacuum freeze drier, YK-118-50, TrueTen Industries, Korea, 1995) to obtain dry weight. The RDM content was then obtained from the ratio of dry weight to fresh weight and expressed as a percentage $(\mathrm{RDM}=100 *$ Dry weight/Fresh weight $)$ according to 
Table 1 Description of the nine yam bean parents used in the study for hybridisation

\begin{tabular}{llllll}
\hline Accession No. & Accessions name & Species & Growth habit & Origin & RDM classification \\
\hline 1 & 209013 & P. tuberosus & Climbing & Peru & High RDM \\
2 & 209014 & P. tuberosus & Climbing & Peru & High RDM \\
3 & 209015 & P. tuberosus & Climbing & Peru & High RDM \\
4 & 209004 & P. ahipa & Bushy-erect & Bolivia & Low RDM \\
5 & 209016 & P. ahipa & Bushy-erect & Guatemala & Low RDM \\
6 & 209022 & P. ahipa & Bushy-erect & Bolivia & Low RDM \\
7 & 209018 & P. erosus & Climbing & Mexico & Low RDM \\
8 & 209019 & P. erosus & Climbing & Mexico & Low RDM \\
9 & 209031 & P. erosus & Climbing & Bolivia & Low RDM
\end{tabular}

Accession names are codes given by the gene bank at international potato center (CIP) in Lima Peru, RDM storage root dry matter content, Low RDM $<20 \%$, High RDM $>20 \%$

Table 2 The crossing scheme for nine parents and their 16 yam bean crosses generated using NCD II

\begin{tabular}{|c|c|c|c|c|}
\hline \multicolumn{2}{|c|}{ Female Parents (Low RDM) } & \multicolumn{3}{|c|}{ Male Parents: P. tuberosus chuin cultivar (High RDM) } \\
\hline & & 209013 & 209014 & 209015 \\
\hline \multirow[t]{3}{*}{ P. ahipa } & 209004 & $209004 \times 209013$ & $209004 \times 209014$ & $209004 \times 209015$ \\
\hline & 209016 & $209016 \times 209013$ & $209016 \times 209014$ & $209016 \times 209015$ \\
\hline & 209022 & $209022 \times 209013$ & $209022 \times 209014$ & NS \\
\hline \multirow[t]{3}{*}{ P. erosus } & 209018 & $209018 \times 209013$ & $209018 \times 209014$ & $209018 \times 209015$ \\
\hline & 209019 & $209019 \times 209013$ & $209019 \times 209014$ & $209019 \times 209015$ \\
\hline & 209031 & $209031 \times 209013$ & $209031 \times 209014$ & NS \\
\hline
\end{tabular}

RDM storage root dry matter content (Low RDM $<20 \%$, High RDM $>20 \%$ ), NS Crosses not realised due to persistent flower abortions after crossing

Wilken et al. (2008). The RDM was used to estimate storage root dry yield (RDY) defined as the proportion of storage root fresh yield (RFY) that remains after drying. RDY was obtained as RDY $=\mathrm{RFY} * \mathrm{RDM}$ and recorded as $\mathrm{t} \mathrm{ha}{ }^{-1}$. Estimation of RDY gives an indication of the processing value of the crop for instance utility in flour based products. Next, each freeze dried sample was ground into flour using a stainless steel mill (Dayton split phase motor-3383L70, Thomas Scientific-USA) fitted with a $0.425 \mathrm{~mm}$ sieve. The flour samples were stored in Kraft paper bags in deep freezers at $-20{ }^{\circ} \mathrm{C}$ until Near-Infrared Reflectance Spectroscopy (NIRS) analysis was conducted.

The NIRS system 5000-M, FOSS scientific 2000 was used to determine starch (STA), and protein (PRO) content as described by Velasco and Grüneberg
(1999) for yam bean with modifications. Instead of fresh storage roots, samples of storage root flour were used, following procedure described for sweetpotato by Tumwegamire et al. (2011). Each flour sample was scanned on NIRS three times to obtain replicates of near-infrared spectra within the range of 400 to $2500 \mathrm{~nm}$. The NIRS calibrations for yam bean freeze dried storage root samples are available at the NQL, NaCRRI in Uganda and were bench marked at Plant and Nutrition Quality Laboratory at CIP in Lima, Peru as reported by Grüneberg 2016.

\section{Data analysis}

The data were subjected to analysis of variance to estimate genetic parameters and test the significance of trait variability across the $83 \mathrm{~F}_{3}$ yam bean families. 
Genotypic and phenotypic coefficients of variation and heritability $\left(h^{2}\right)$ estimates were calculated from variance components according to Kearsey and Pooni (1996) and Singh and Chaudhary (1985) following the formulas:

Genotypic coefficient of variation $(\mathrm{GCV} \%)$

$$
=\frac{\sqrt{ } \sigma_{\mathrm{g}}^{2}}{\dot{\mathrm{x}}} * 100
$$

Phenotypic coefficient of variation $(\mathrm{PCV} \%)$

$$
=\frac{\sqrt{ } \sigma_{\mathrm{g}}^{2}}{\dot{\mathrm{x}}} * 100
$$

Then narrow sense heritability $\left(\mathrm{h}_{\mathrm{b}}^{2}\right)$ was determined following Kearsey and Pooni (1996) as follows:

$h^{2}=\frac{\sigma_{\mathrm{g}}^{2}}{\sigma_{\mathrm{g}}^{2}+\sigma_{\mathrm{e} / \mathrm{r}}^{2}} * 100$

where $\sigma^{2} \mathrm{~g}$ genotypic variance, $\sigma^{2} \mathrm{p}$ phenotypic variance, $\sigma^{2}$ e environmental variance and $\dot{\mathrm{x}}$ grand mean of the trait.

The variance components in the above formulae were calculated from the ANOVA (Table 5) as follows:

$$
\begin{aligned}
& \operatorname{Genotypic} \text { variance }\left(\sigma_{\mathrm{g}}^{2}\right) \\
& =\frac{\text { Genotypic mean square }(\mathrm{GMS})-\text { Error means square(EMS) }}{\text { Number of replications }(r)}
\end{aligned}
$$

Phenotypic variance $\left(\sigma_{\mathrm{p}}^{2}\right)=\sigma_{\mathrm{g}}^{2}+\sigma_{\mathrm{e}}^{2} / r$

Environmental variance $\left(\sigma_{\mathrm{e}}^{2}\right)=\mathrm{MSe}-\left(\sigma_{\mathrm{g}}^{2}\right) / 2$

Then, response to selection $(R)$ and percentage response to selection ( $\mathrm{R} \%$ ) for storage root dry matter and associated traits were calculated as reported by Acquaah (2007) using the formula:

Response to $\operatorname{selection}(R)=i h^{2} \sigma_{\mathrm{p}}$

Percentage response to selection $(R \%)=(\mathrm{R} / \dot{\mathrm{x}}) * 100$

where $i$ selection intensity, $\mathrm{h}^{2}$ narrow sense heritability, $\dot{x}$ overall trait mean, $\sigma_{\mathrm{p}}$ phenotypic standard deviation of the parental population (selection differential i.e. the mean phenotypic value of the individuals selected as parents expressed as a deviation from the population mean) and is calculated using the formula:

$\sigma_{\mathrm{p}}=\sqrt{\left(\sigma_{\mathrm{p}}^{2}\right)}=\sqrt{\sigma_{g}^{2}+\frac{\sigma_{e}^{2}}{\mathrm{r}}}$

The selection intensity $(i)$ of 1.755 corresponding to $10 \%$ was used as described by Acquaah (2007).

\section{Results}

Variability of RDM and associated traits

The mean squares from combined analysis of variance for RDM and associated traits among the selected 83 $\mathrm{F}_{3}$ yam bean families are presented in Table 3. There was significant $(P<0.001)$ genetic variation among the 83 yam bean families for all the eight traits, RDM, FRY, RDY, HI, VNY, FBY, STA and PRO. The within family variation was non-significant across traits.

Mean performance, phenotypic and genotypic variance components

There were wide phenotypic variations among the families as shown by the higher than unity values of $\sigma_{p}^{2}$ and $\sigma_{g}^{2}$ for five out of the eight RDM and associated traits, viz., RDM, RFY, HI, FBY and STA (Table 4). The STA varied most with phenotypic and genotypic variance of 59.33 and 43.79 followed by $\mathrm{HI}$ with 23.30 and 12.32 respectively. RDY varied the least among the eight traits assessed. The mean RDM ranged from 12.43 to $31.83 \%$ with a population average of $22.4 \%$ while the mean STA content on dry weight basis was $64.38 \%$. These values were higher than the corresponding estimates in the respective parent populations previously reported as $15.3 \%$ and $52.3 \%$ for RDM and STA, respectively (Agaba et al. 2016) and pre-selection populations at $F_{1}$ and $F_{2}$ (Agaba et al. 2017). The yield of storage roots across the progenies ranged from a minimum of 2.6 to a maximum $19 \mathrm{t} \mathrm{ha}^{-1}$ with a mean of $7.58 \mathrm{t} \mathrm{ha}^{-1}$ (Table 4).

Genetic and environmental variances and coefficients of variation

The estimates of genetic and environmental variances, genotypic coefficient of variation (GCV) and phenotypic coefficient of variation (PCV) for dry matter and 
Table 3 Analysis of variance for storage root dry matter and associated traits in $\mathrm{F}_{3}$ yam bean population evaluated at NaCRRI, Namulonge, during the rainy season of April 2015

\begin{tabular}{|c|c|c|c|c|c|c|c|c|c|}
\hline \multirow[t]{2}{*}{ Source of variation } & \multicolumn{9}{|c|}{ Mean squares } \\
\hline & df & $\begin{array}{l}\text { RDM } \\
(\%)\end{array}$ & $\begin{array}{l}\text { RFY } \\
\left(\mathrm{t} \mathrm{ha}^{-1}\right)\end{array}$ & $\begin{array}{l}\text { RDY } \\
\left(\mathrm{t} \mathrm{ha}^{-1}\right)\end{array}$ & $\begin{array}{l}\mathrm{HI} \\
(\%)\end{array}$ & $\begin{array}{l}\text { VNY } \\
\left(\mathrm{t} \mathrm{ha}^{-1}\right)\end{array}$ & $\begin{array}{l}\text { FBY } \\
\left(\mathrm{t} \mathrm{ha}^{-1}\right)\end{array}$ & $\begin{array}{l}\text { STA } \\
(\%)\end{array}$ & $\begin{array}{l}\text { PRO } \\
(\%)\end{array}$ \\
\hline Replication & 2 & $42.71^{\mathrm{ns}}$ & $32.1 \mathrm{~ns}$ & $4.53 \mathrm{~ns}$ & $585.6 \mathrm{~ns}$ & $2.51 \mathrm{~ns}$ & $118.41 \mathrm{~ns}$ & $310.5 \mathrm{~ns}$ & $26.52 \mathrm{~ns}$ \\
\hline Between families & 82 & $195.38 * * *$ & $53.5 * * *$ & $3.72 * * *$ & $355.7 * * *$ & $12.83 * * *$ & $100.03 * * *$ & $911.8 * * *$ & $13.56 * * *$ \\
\hline Within families & 1162 & $59.86 \mathrm{~ns}$ & $23 \mathrm{~ns}$ & $1.41 \mathrm{~ns}$ & $170.89 \mathrm{~ns}$ & $6.18 \mathrm{~ns}$ & $38.07 \mathrm{~ns}$ & $254.97 \mathrm{~ns}$ & $6.03 \mathrm{~ns}$ \\
\hline $\begin{array}{l}\text { Coefficient of variation (CV } \\
\%)\end{array}$ & & 16. 3 & 17.4 & 9.2 & 15.1 & 15.3 & 19.3 & 19.9 & 7.1 \\
\hline
\end{tabular}

$n s$ non-significant mean squares, $R D M$ root dry matter content, $R F Y$ fresh root yield, $R D Y$ root dry yield, $V N Y$ vine yield, $F B Y$ fresh biomass yield, $H I$ harvest index, $P R O$ protein content of roots, STA starch content of roots

Significance level, $* * *$ at 0.001

Table 4 Mean performance, phenotypic and genotypic variance components for $\mathrm{F}_{3}$ yam bean population evaluated at NaCRRI, Namulonge, during the first rainy season of April, 2015

\begin{tabular}{|c|c|c|c|c|c|c|}
\hline \multirow[t]{2}{*}{ Trait } & \multicolumn{2}{|l|}{ Range } & \multirow{2}{*}{$\begin{array}{l}\text { Mean } \\
(\dot{x})\end{array}$} & \multirow[t]{2}{*}{ S.e.m } & \multicolumn{2}{|c|}{ Variance component } \\
\hline & Min & Max & & & $\sigma_{p}^{2}$ & $\sigma_{g}^{2}$ \\
\hline RDM, \% & 12.43 & 31.83 & 22.40 & 0.44 & 12.72 & 9.03 \\
\hline $\mathrm{RFY}, \mathrm{t} \mathrm{ha}^{-1}$ & 2.60 & 19.00 & 7.58 & 0.28 & 3.50 & 2.03 \\
\hline RDY, $\mathrm{t} \mathrm{ha}^{-1}$ & 0.47 & 3.76 & 1.65 & 0.06 & 0.24 & 0.15 \\
\hline HI, \% & 54.74 & 86.70 & 75.28 & 0.63 & 23.30 & 12.32 \\
\hline VNY, t ha ${ }^{-1}$ & 0.79 & 7.66 & 2.64 & 0.13 & 0.84 & 0.44 \\
\hline FBY, t ha ${ }^{-1}$ & 3.37 & 28.35 & 10.21 & 0.39 & 6.53 & 4.13 \\
\hline STA, \% & 35.80 & 81.55 & 64.38 & 0.96 & 59.33 & 43.79 \\
\hline PRO, \% & 9.89 & 15.07 & 12.10 & 0.12 & 0.89 & 0.50 \\
\hline
\end{tabular}

RDM root dry matter content, $R F Y$ fresh root yield, $R D Y$ root dry yield, $V N Y$ Vine yields, $F B Y$ fresh biomass yield, $H I$ harvest index, $P R O$ protein content of roots, STA starch content of roots, S.e.m standard error of the mean, $\sigma^{2} p$ phenotypic variation, $\sigma^{2} g$ genotypic variation

associated traits are presented in Table 5. The genetic variances were high for RDM, RFY, RDY, HI, FBY and STA. The estimates of GCV were moderate for STA (10.28), RDM (13.42), RFY (18.8), RDY (23.71), FBY (19.91) and VNY (25.25). The PCV and GCV estimates were low to moderately high at 6.41 and 34.77 for in $\mathrm{HI}$ and VNY, respectively.

Heritability and response to selection estimates

The estimates of narrow sense heritability, response to selection $(R)$ and $R$ percentage for the eight evaluated traits are also presented in Table 5. In the current study, narrow sense heritability was moderately high ( 0.53 to 0.74$)$ and associated with high estimates of $R$ indicating that all the traits were highly heritable with potential for improvement. For a single cycle of selection in early generations, percentage response to selection (R\%) of 15.5 to $33.12 \%$ is achievable for RDM, RFY, RDY, VNY, FBY and STA. But heritability and percentage response to selection for HI (0.53) and PRO (0.57) were low at $5.95 \%$ and $7.73 \%$, respectively, suggesting that improvement of $\mathrm{HI}$ and PRO in yam beans would require several cycles of selection. 
Table 5 Estimates of genetic and environmental variance, coefficient of variation, heritability and response to selection for storage root dry matter and associated traits among $83 \mathrm{~F}_{3}$ yam bean families

\begin{tabular}{|c|c|c|c|c|c|c|c|c|}
\hline Parameter & $\begin{array}{l}\text { RDM } \\
(\%)\end{array}$ & $\begin{array}{l}\text { RFY } \\
\left(\mathrm{t} \mathrm{ha}^{-1}\right)\end{array}$ & $\begin{array}{l}\text { RDY } \\
\left(\mathrm{t} \mathrm{ha}^{-1}\right)\end{array}$ & $\begin{array}{l}\mathrm{HI} \\
(\%)\end{array}$ & $\begin{array}{l}\text { VNY } \\
\left(\mathrm{t} \mathrm{ha}^{-1}\right)\end{array}$ & $\begin{array}{l}\text { FBY } \\
\left(\mathrm{t} \mathrm{ha}^{-1}\right)\end{array}$ & $\begin{array}{l}\text { STA } \\
(\%)\end{array}$ & $\begin{array}{l}\text { PRO } \\
(\%)\end{array}$ \\
\hline Genetic variance $\left(\sigma_{\mathrm{g}}^{2}\right)$ & 9.03 & 2.03 & 1.33 & 12.32 & 0.44 & 4.13 & 43.79 & 0.50 \\
\hline Environmental variance $\left(\sigma_{\mathrm{E}}^{2}\right)$ & 55.34 & 21.98 & 1.33 & 164.73 & 5.96 & 36.00 & 233.08 & 5.78 \\
\hline Phenotypic standard deviation $\left(\sigma_{\mathrm{p}}\right)$ & 3.57 & 1.87 & 0.49 & 4.83 & 0.92 & 2.56 & 7.70 & 0.94 \\
\hline Phenotypic coefficient of variation (PCV \%) & 15.93 & 24.66 & 29.78 & 6.41 & 34.77 & 25.04 & 11.96 & 7.78 \\
\hline Genetic coefficient of variation (GCV \%) & 13.42 & 18.80 & 23.71 & 4.66 & 25.25 & 19.91 & 10.28 & 5.86 \\
\hline Narrow sense heritability $\left(\mathrm{h}^{2}\right)$ & 0.71 & 0.58 & 0.63 & 0.53 & 0.53 & 0.63 & 0.74 & 0.57 \\
\hline Response to selection $(\mathrm{R})^{\mathrm{a}}$ & 4.45 & 1.91 & 0.55 & 4.48 & 0.85 & 2.84 & 9.98 & 0.94 \\
\hline $\mathrm{R}$ as a percentage of mean $(\mathrm{R} \%)$ & 19.85 & 25.14 & 33.12 & 5.95 & 32.18 & 27.79 & 15.50 & 7.73 \\
\hline
\end{tabular}

$R D M$ root dry matter content, $R F Y$ fresh root yield, $R D Y$ root dry yield, $V N Y$ vine yields, $F B Y$ fresh biomass yield, $H I$ harvest index, $P R O$ protein content of roots, STA starch content of roots

${ }^{a}$ Response to selection was calculated at $10 \%$ selection intensity (1.75 selection differential)

Genetic correlations for RDM and associated traits

The genotypic correlation coefficients for the eight $\mathrm{RDM}$ and associated traits among the $83 \mathrm{~F}_{3}$ yam bean families are presented in Table 6. RDM had significant $(P<0.001)$ positive correlations with RDY and STA but negative relationship with PRO. RFY had significant $(P<0.001)$ correlations with RDY, VNY and FBY. The correlations between RDY and VNY, FBY and STA were significant $(P<0.001)$ while correlations between VNY and FBY were both strong $(\mathrm{r}=0.786)$ and significant $(P<0.001)$. The RPO had negative and significant $(P<0.05)$ correlations with RFY, RDY, FBY and STA implying that it would be difficult to select for simultaneous improvement of these traits in the studied population of yam beans.

\section{Discussion}

This study investigated genetic parameters and response to selection for storage root dry matter and associated traits in $83 \mathrm{~F}_{3}$ families selected from a population of 16 interspecies crosses of yam beans. From the ANOVA results (Table 3), highly significant differences $(P<0.001)$ observed among the 83

Table 6 Estimates of genetic correlation coefficients among root dry matter and associated traits in $\mathrm{F}_{3}$ yam bean selected populations evaluated at NaCRRI, Namulonge during rainy season of April 2015

\begin{tabular}{|c|c|c|c|c|c|c|c|}
\hline & RDM (\%) & RFY $\left(\mathrm{t} \mathrm{ha}^{-1}\right)$ & $\operatorname{RDY}\left(\mathrm{t} \mathrm{ha}^{-1}\right)$ & HI (\%) & VNY $\left(\mathrm{t} \mathrm{ha}^{-1}\right)$ & $\operatorname{FBY}\left(\mathrm{t} \mathrm{ha}^{-1}\right)$ & STA $(\%)$ \\
\hline RDM (\%) & 1 & & & & & & \\
\hline $\operatorname{RFY}\left(\mathrm{t} \mathrm{ha}^{-1}\right)$ & -0.123 & 1 & & & & & \\
\hline $\operatorname{RDY}\left(\mathrm{t} \mathrm{ha}^{-1}\right)$ & $0.408 * * *$ & $0.809 * * *$ & 1 & & & & \\
\hline $\mathrm{HI}(\%)$ & 0.01 & 0.146 & 0.166 & 1 & & & \\
\hline $\operatorname{VNY}\left(\mathrm{t} \mathrm{ha}^{-1}\right)$ & -0.091 & $0.612 * * *$ & $0.488 * * *$ & $-0.493 * * *$ & 1 & & \\
\hline FBY $\left(\mathrm{t} \mathrm{ha}^{-1}\right)$ & -0.117 & $0.963 * * *$ & $0.771 * * *$ & -0.083 & $0.786 * * *$ & 1 & \\
\hline STA (\%) & $0.699 * * *$ & 0.046 & $0.422 * * *$ & $0.268^{*}$ & -0.128 & -0.007 & 1 \\
\hline PRO (\%) & $-0.320 * *$ & $-0.217^{*}$ & $-0.334 * *$ & 0.045 & -0.201 & $0.231 *$ & $-0.295^{*}$ \\
\hline
\end{tabular}

$R D M$ root dry matter content, $R F Y$ fresh root yield, $R D Y$ root dry yield, $H I$ harvest index, $V N Y$ vine yields, $F B Y$ fresh biomass yield, STA starch content, $P R O$ protein content

$*, * *, * * *, * * *$ significant at $0.05,0.01$, and 0.001 respectively 
families for the eight traits (RDM, RFY, RDY, HI, VNY, STA and PRO) show the presence of high genetic variability. This suggests that improvement of yam beans for RDM and associated traits is possible and can be exploited by breeders through hybridisation and recurrent selection to develop high yielding, and high dry matter cultivars. The presence of high variability could be due to the wide genetic distances between the three species used as parents ( $P$. tuberosus, $P$. erosus and $P$. ahipa) to generate the crosses. These results agree with the findings by Zanklan et al. (2007) who reported large genetic variation within and among the three cultivated yam bean species for traits such as root dry matter content, root fresh yield, root dry yield, biomass yield, harvest index, protein and starch contents. The results of this study are further comparable to those of Agaba et al. (2017) who reported presence of significant genetic variation for RDM and associated traits between 16 crosses of yam beans before selection and between the parents used to generate the crosses. Even within yam bean species, distinct groups can be found with clear genetic distances, for instance $P$. tuberosus can be subgrouped based on morpho-agronomic traits into four cultivar groups namely; Chuin, Yushpe, Ashipa and Jiquima (Zanklan et al. 2018). Tapia and Sørensen (2003) reported high genetic variation among the four cultivar groups of $P$. tuberosus and hypothesised high genetic potential for improvement of morphological traits in yam beans. Similarly, in a genetic diversity study of 10 morpho-agronomic traits in 64 yam bean genotypes (Pachyrhizus spp.), Silva et al. (2016) reported presence of significant genetic variability and concluded that the variation in yam beans could be used for improvement of storage root yields and associated traits. The results of our study and the existing evidence in literature for high genetic variation support a new hypothesis that most morphoagronomic traits in yam beans are predominantly controlled by additive genetic effects. Nevertheless, this study showed relatively high environmental variance for RFY, FBY, RDM, STA and HI, which reveal that environmental factors could influence the expression of these traits and limit the performance of the evaluated yam bean population in diverse environments.

The results in Table 5 show moderate to high GCV estimates for RDM, STA, RFY, FBY, RDY and VNY indicating that improvement of these traits is possible. The difference between GCV and PCV estimates was small in most traits except $\mathrm{HI}$ and PRO content, implying minimal influence of environmental factors in the expression of these traits which confirms the good prospects for genetic improvement of the traits. According to Akinwale et al. (2010), large differences between GCV and PCV reflect high environmental influence, while smaller differences reveal high genetic influence. The estimation of both coefficients of variation (GCV and PCV), and heritability gives a better indication of the genetic potential for response to selection. Genetic coefficients of variation, heritability and response to selection are important in designing suitable selection procedures and efficient breeding programs. GCV is a measure of relative genetic variation of a trait in a population and traits with high GCV estimates may respond favorably to selection (Jamoza et al. 2014). Low estimates of GCV were observed for PRO in this study, implying that selection might be ineffective in early generations and should be delayed till later generations (F5-F6). Delaying selection to later generations when additive genetic effects are fixed might be the appropriate breeding strategy for improvement of such traits. In view of the high genotypic variation and coefficients of variation observed for most traits in this study, selection for $\mathrm{RDM}$ and associated traits provides opportunities for yam bean improvement.

The results in this study further showed moderate to high narrow sense heritability estimates $(0.53$ to $0.74)$ for the dry matter content and associated traits (Table 5). This is a good indicator that a large proportion of the total variance could be passed on to progenies and that breeding values can be reliably predicted based on phenotypic mean values as reliable selection indicators for these traits. This argument is supported by Falconer and Mackay (1996) who reported that heritable variation shows the reliability of phenotypic values in predicting the breeding value of quantitative traits in a breeding population. The heritability estimate for dry matter content of 0.71 was higher than the previously reported value (0.66) in 31 P. tuberosus accessions by Tapia and Sørensen (2003). Nevertheless, the heritability reported by Tapia and Sørensen was from a natural population of one species ( $P$. tuberosus) while the heritability estimates reported in this study are for a selected population from the three yam bean interspecies crosses. Recent 
studies, based on $F_{2}$ populations from interspecies crosses among the three yam bean species reported high heritability of 0.88 (Ndirigwe et al. 2020) and 0.75 (Agaba et al. 2017) for RDM without selection. These findings show that the use of $P$. tuberosus chuin cultivar in hybridisation boosts the genetic potential for improvement of dry matter content and associated traits and strengthens the argument for archiving effective selection in yam beans.

The effectiveness of selecting for desired traits in breeding programs depends not only on high genetic variation and heritability but also on the magnitude of response to selection $(R)$ for the target traits. The results in Table 5 further show high percentage response to selection $(R \%)$ ranging from $5.95 \%$ to $33.12 \%$ for RDM, RFY, FBY and STA, indicating high potential for genetic improvement of the evaluated population through recurrent selection. On the contrary, the combination of low estimates for heritability, GCVs and response to selection for $\mathrm{HI}$ and PRO (Table 4) suggests that it is difficult to improve these traits in the current yam bean population. In crop improvement programs, the estimation of genetic parameters especially narrow sense heritability and response to selection is important for selecting the best promising parents, progenies and designing effective breeding procedures for new cultivars.

The combination of high heritability estimates and high R\% for most traits obtained in this study confirms that RDM and associated traits in yam beans are largely controlled by additive genetic effects. This demonstrates that alleles for high RDM and associated traits can be easily transmitted to the offspring through recombination. The high percentage response to selection ( $\mathrm{R} \%$ ) observed from a single cycle of selection in early generations of yam bean populations clearly shows the value for implementing a breeding program to improve RDM and associated traits especially RDM, STA, RFY, FBY and RDY. Such a breeding program would benefit from high response to selection, reduce time and resources while advancing early segregating populations. This would lead to fast development of high RDM yam bean varieties with potential for wide adoption in East Africa where high dry matter is preferred among root crop dependent communities (Tumwegamire et al. 2011).

The results of genetic correlation analysis (Table 6) revealed highly significant correlations between RDM and RDY as well as STA but negative with RFY and PRO indicating that early generation selection for high dry matter content would simultaneously improve storage root dry yield and starch content of yam bean but negatively affect storage root yields and protein content. More so, the significant association of RFY with RDY, VNY and FBY suggest that selection of progenies with high vine yields would indirectly improve RFY as well as RDY and that above ground biomass has considerable positive effects on the storage root yields in yam bean. Such positive and significant correlations are essential for selection of superior genotypes that would combine several desirable quantitative traits. The magnitude of correlation coefficients indicates a measure of genetic association among quantitative traits which informs choice of breeding strategy that would maximize genetic gains and quicken crop improvement. According to Falconer and Mackay (1996), the extent of correlated response is a function of the heritability of the correlated traits, as well as the genetic correlation between the traits. As previously supported by (Agaba et al. 2017) that dry matter content in yam beans is highly related to yield traits, our results confirm this assertion by the strong and positive correlation coefficients and suggest that simultaneous improvement is possible for both traits through selection. The current correlation coefficients show strong and large common variation among traits indicating possibility for combined improvement which might inform future selection procedures and breeding plans in yam bean. This means that the relationships among traits are reliable indicators of genetic potential for simultaneous improvement of RDM and associated traits.

\section{Conclusion}

This study presents the first set of results on response to selection and percentage response to selection in the yam bean gene pool. The results suggest little intra family responses for various traits. For effective genetic gains therefore, intra family crosses are discouraged at least among these selected introductions. The study showed that interspecies hybridisation followed by early generation selection could be effectively utilized for improvement of RDM, RFY, RDY, VNY, FBY and starch content in yam beans. The high genetic variance and heritable variation 
observed in yam beans translate into substantial response to selection for RDM, RFY, RDY, HI, FBY and STA in one cycle of early generation selection. These findings further demonstrate that worthwhile genetic progress of more than $15 \%$ on mean basis is achievable for RDM, RFY, RDY, FBY, and STA which shows potential for rapid improvement of these traits in a yam bean breeding program.

Acknowledgements This research was undertaken as part of, and funded by, the CGIAR Research Program on Roots, Tubers and Bananas (RTB) and supported by CGIAR Trust Fund contributors. Additional funding for was provided by Belgium Development Corporation (BTC) through International Potato Center (CIP), and Carnegie Corporation of New York through the Regional Universities Forum for Capacity Building in Agriculture (RUFORUM). https://www.cgiar.org/funders/.

\section{Compliance with ethical standards}

Conflict of interest The authors declare that they have no conflict of interest.

Open Access This article is licensed under a Creative Commons Attribution 4.0 International License, which permits use, sharing, adaptation, distribution and reproduction in any medium or format, as long as you give appropriate credit to the original author(s) and the source, provide a link to the Creative Commons licence, and indicate if changes were made. The images or other third party material in this article are included in the article's Creative Commons licence, unless indicated otherwise in a credit line to the material. If material is not included in the article's Creative Commons licence and your intended use is not permitted by statutory regulation or exceeds the permitted use, you will need to obtain permission directly from the copyright holder. To view a copy of this licence, visit http://creativecommons.org/licenses/by/4.0/.

\section{References}

Acquaah G (2007) Principles of plant genetics and breeding, 1st edn. Wiley-Blackwell Publishers, Malden UK

Adegbola PY, Nestor AA, Houessionon P, Alokpai N, Hell K, Thiele G, Fandohan P and Mensah GA (2015) Socio-economic analysis of Pachyrhizus erosus cultivation in Benin: profitability and cost function analysis. In: Proceedings of 29th ICAE. Milan, Italy 9-14 August 2015

Agaba R, Tukamuhabwa P, Rubaihayo P, Tumwegamire S, Ssenyonjo S, Mwanga ROM, Ndirigwe J, Gruneberg WJ (2016) Genetic variability for yield and nutritional quality in yam bean (Pachyrhizus sp.). HortScience 51(9):1079-1086. https://doi.org/10.21273/ HORTSCI10686-16

Agaba R, Tukamuhabwa P, Rubaihayo P, Mwanga ROM, Ssenyonjo A, Ndirigwe J, Tumwegamire S, Gruneberg W (2017) Heritability, combining ability and inheritance of storage root dry matter in yam beans. Afr Crop Sci J 25(1):83-95

Akinwale M, Akinyele B, Dixon A, Odiyi A (2010) Genetic variability among forty-three cassava genotypes in three agro-ecological zones of Nigeria. J Plant Breed Crop Sci 2:104-109

Ddamulira G, Santos CAF, Obuo P, Alanyo M, Lwanga CK (2015) Grain yield and protein content of Brazilian Cowpea genotypes under diverse Ugandan environments. AJPS 6:2074-2084

Delêtre M et al (2017) Ecotypic differentiation under farmers' selection: Molecular insights into the domestication of Pachyrhizus Rich. ex DC. (Fabaceae) in the Peruvian Andes. Evol Appl 10:498-513

Falconer D, Mackay T (1996) Introduction to quantitative genetics, 4th edn. Longman Group Ltd, Essex

Gegios A et al (2010) Children consuming cassava as a staple food are at risk for inadequate zinc, iron, and vitamin A intake. Plant Foods Hum Nutr 65:64-70. https://doi.org/10. 1007/s11130-010-0157-5

Grum M (1994) Breeding of new yam bean (Pachyrhizus Rich. ex DC.) Cultivars in Tonga involving interspecific hybrids. In: Sørensen M (ed) Proceedings of the first international symposium on tuber legumes; Guadeloupe, F.W.I. Jordbrugsforlaget, Copenhagen (Denmark), pp 315-320

Grüneberg WJ, Goffman FD, Velasco L (1999) Characterization of yam bean (Pachyrhizus spp.) seeds as potential sources of high palmitic acid oil JAOCS. J Am Oil Chem Soc 76:1309-1312

Grüneberg WJ (2016) Enhancing the nutrient-rich yam bean (Pachyrhizus spp.) storage roots to improve food quality and availability and sustainability of farming systems in Central and West Africa. International Potato Center Report No. 978-92-9060-474-7. https://goo.gl/ovVCNL, doi:https://doi.org/10.4160/9789290604747, p 267

Grüneberg WJ, Freynhagen-Leopold P, Delgado-Váquez O (2003) A new yam bean (Pachyrhizus spp.) interspecific hybrid. Genet Resour Crop Evol 50:757-766

Gupta K, Talwar G, Jain V, Dhawan K, Jain S (2003) Salad crops root, bulb, and tuber crops. Encycl Food Sci 5060-5073. https://doi.org/10.1016/B0-12-227055-X/ 01040-3

Heider B et al (2011) Nutritional improvement of yam bean and sustainability of farming systems in Central and West Africa. Afr Crop Sci J 10:93-95

Jamoza J, Owuoche J, Kiplagat O, Opile W (2014) Broad-sense heritability estimation and correlation among sugarcane (Saccharum spp. hybrids) yield and some agronomic traits in western Kenya. IJAPR 2:16-25

Jha V, Singh B (2014) Combining ability analysis for quantitative traits in yam bean [Pachyrhizuserosus (L.) Urb.]. Ann Agri Bio Res 19:243-246

Kearsey MJ, Pooni HS (1996) The genetical analysis of quantitative traits. Stanley Thornes (Publishers) Ltd, United Kingdom

Ndirigwe J et al (2020) Genetic variability and gain for storage root yield and yield components in yam beans. Afr Crop Sci J 28:33-47. https://doi.org/10.4314/acsj.v28i1.4

Oloyede-Kamiyo QO, Ajala SO, Akoroda MO (2014) Estimates of genetic variances and relationship among traits associated with stem borer resistance in maize (Zea mays L.). 
Field Crop Res 166:137-143. https://doi.org/10.1016/j.fcr. 2014.05.014

Padonou S et al (2013) Yam bean (Pachyrhizus erosus) tuber processing in Benin: production and evaluation of the quality of yam bean-gari and yam bean-fortified gari. IJBCS 7:247-259. https://doi.org/10.4314/ijbcs.v7i1i.21

Popoola J, Ojuederie O, Omonhinmin C, Adegbite A (2019) Neglected and underutilized legume crops: Improvement and future prospects. In: Recent advances in grain crops research. IntechOpen, [Online First]. https://doi.org/10. 5772/intechopen.87069

Primiani CN (2015) The phytoestrogenic potential of Yam Bean (Pachyrhizus erosus) on ovarian and uterine tissue structure of premenopausal mice. Biol Med Nat Prod Chem 4(1):4-9

Ramos-de-la-Peña AM, Renard CM, Wicker L, Montañez J, de la Luz R-V, Contreras-Esquivel JC (2012) Optimization of the liquefaction and saccharification of structural polysaccharides of jicama (Pachyrhizus erosus L.) tissue by enzymatic pulping. LWT-Food Sci Technol 46:232-238. https://doi.org/10.1016/j.1wt.2011.10.001

Roychowdhury R, Datta S, Gupta P, Jagatpati T (2012) Analysis of genetic parameters on mutant populations of mungbean (Vigna radiata L.) after ethyl methane sulphonate treatment. Not Sci Biol 4(1):137

Santayana M et al (2014) (2014) Molecular characterization of cultivated species of the genus Pachyrhizus Rich. ex DC. by AFLP markers: call- ing for more data. Trop Plant Biol 7:121-132. https://doi.org/10.1007/s12042-014-9143-7

da Silva ES, da Silva FDF, Ticona-Benavente CA (2016) Diversity of yam bean (Pachyrhizus spp. Fabaceae) based on morphoagronomic traits in the Brazilian Amazon. Acta Amazon 46(3):233-324. https://doi.org/10.1590/18094392201504774

Singh RK, Chaudhary BD (1985) Biometrical methods in quantitative genetic analysis. Kalayani Publishers, New Delhi

Sørensen M (1990) Observations on distribution, ecology and cultivation of the tuber-bearing legume genus Pachyrhizus Rich. ex DC (Fabaceae: Phaseoleae). In: Wageningen Agricultural University Papers (Netherlands), vol 90, pp 1-38
Sørensen M (1996) Yam bean (Pachyrhizus DC.) Promoting the conservation and use of underutilized and neglected crops. In: Heller J (ed.) Institute of Plant Genetics and Crop Plant Research, Gatersleben/International Plant Genetic Resources Institute, Rome, vol 2, p 141

Tapia C, Sørensen M (2003) Morphological characterization of the genetic variation existing in a neotropical collection of yam bean, Pachyrhizus tuberosus (Lam.) Spreng. Genet Resour Crop Evol 50:681-692

Tumuhimbise R, Melis R, Shanahan P, Kawuki R (2014) Genotype $\times$ environment interaction effects on early fresh storage root yield and related traits in cassava. Crop J 2:329-337. https://doi.org/10.1016/j.cj.2014.04.008

Tumwegamire $S$ et al (2011) Evaluation of dry matter, protein, starch, sucrose, $\beta$-carotene, iron, zinc, calcium, and magnesium in East African sweetpotato [Ipomoea batatas (L.) Lam] germplasm. HortScience 46:348-357

Velasco L, Grüneberg WJ (1999) Analysis of dry matter and protein contents in fresh yam bean tubers by near-infrared reflectance spectroscopy. Commun Soil Sci Plant Anal 30:1797-1805

Wilken MF, Erickson GE, Benton JR, Buckner CD, Klopfenstein TJ, Karges K, Gibson M (2008) Evaluation of methods for dry matter determination of ethanol byproducts. Nebraska Beef Cattle Reports Paper 49. http:// digitalcommons.unl.edu/animalscinbcr/49

Yang RC (2009) When is early generation selection effective in self-pollinated crops? Crop Sci 49(6):2065-2070

Zanklan AS, Ahouangonou S, Becker HC, Pawelzik E, Grüneberg WJ (2007) Evaluation of the storage root-forming Legume Yam Bean (spp.) under West African conditions. Crop Sci 47(5):1934-1946

Zanklan AS, Becker HC, Sørensen M, Pawelzik E, Grüneberg WJ (2018) Genetic diversity in cultivated yam bean (Pachyrhizus spp.) evaluated through multivariate analysis of morphological and agronomic traits. Genet Resour Crop Evol 65:811-843. https://doi.org/10.1007/s10722-0170582-5

Publisher's Note Springer Nature remains neutral with regard to jurisdictional claims in published maps and institutional affiliations. 